\title{
Study on pharmacognostical properties of leaf of Helicteres isora L.
}

\section{Chitra}

\begin{abstract}
The micro morphology of the leaves of Helicteres isora L. (Sterculiaceae) was explored. The leaves are serrate, obliquely cordite or ovate, shortly acuminate and rough above and pubescent beneath. Microscopic analysis was informative and provides useful information in the botanical identification, standardization for purity and quality and immense value in authentication of the leaf. Microscopic evaluation of leaves revealed the presence the midrib is broadly conical on the adaxial side and broadly semicircular on the abaxial side. It is $900 \mu \mathrm{m}$ in vertical axis and $450 \mu \mathrm{m}$ along the horizontal abaxial part. The lamina is $200 \mu \mathrm{m}$ thick and has fairly broad, distinct adaxial epidermis of squrish cells. Some of the epidermal cells are dilated and muliagenous. Calcium oxalate druses are abundant in the midrib, lamina and petiole. The lateral veins are uniformly thick forming mostly squarish or rectangular distinct vein-islets. This study of pharmacognostical features of Helicteres isora is useful for the detection of botanical identification and in authentication of the leaf of Helicteres isora $\mathrm{L}$.
\end{abstract}

Key words : Helicteres isora, Sterculiaceae, Microscopical evaluation, Botanical authentication

How to cite this paper : Chitra, M. (2015). Study on pharmacognostical properties of leaf of Helicteres isora L. Ann. Pharm. \& Pharm. Sci., $6(1 \& 2): 8-13$.

Article chronicle : Received : 10.09.2015; Revised : 16.09.2015; Accepted : 20.09.2015 